Article

\title{
Performance of an Auto-Reduced Nickel Catalyst for Auto-Thermal Reforming of Dodecane
}

\author{
Seong Bin Jo ${ }^{1,+}$, Dong Geon Ju ${ }^{2,3,+}$, Suk Yong Jung ${ }^{4}$, Dong Su Ha ${ }^{5}$, Ho Jin Chae ${ }^{2}$, \\ Soo Chool Lee ${ }^{1, *}$ and Jae Chang Kim ${ }^{2, *}$ \\ 1 Research Institute of Advanced Energy Technology, Kyungpook National University, Daegu 41566, Korea; \\ santebin@knu.ac.kr \\ 2 Department of Chemical Engineering, Kyungpook National University, Daegu 41566, Korea; \\ judong1226@nate.com (D.G.J.); hwman777@nate.com (H.J.C.) \\ 3 Korea Evaluation Institute of Industrial Technology (KEIT), Daegu 41069, Korea \\ 4 Wonik Materials Co., Cheongju 28125, Korea; ojhyt@hanmail.net \\ 5 Korea Institute of Energy Research, Daejeon 34129, Korea; suyaa130@naver.com \\ * Correspondence: soochool@knu.ac.kr (S.C.L.); kjchang@knu.ac.kr (J.C.K.); \\ Tel.: +82-53-950-5622 (S.C.L. \& J.C.K.) \\ + Seong Bin Jo and Dong Geon Ju contributed equally to this work.
}

Received: 17 July 2018; Accepted: 20 August 2018; Published: 3 September 2018

\begin{abstract}
To investigate the catalytic performance of diesel reforming catalysts for production of hydrogen gas, Ni-Al catalyst was prepared by the polymer-modified incipient method (NA10-PM). NA10-PM showed excellent catalytic performance and economic feasibility in the auto-thermal reforming reaction, compared to other commercially available catalysts. In particular, auto-reduced NA10-PM showed higher dodecane conversion and similar selectivity at $750{ }^{\circ} \mathrm{C}$ compared to $\mathrm{H}_{2}$-reduced NA10-PM. X-ray diffraction (XRD) studies showed that the fresh state of NA10-PM initially automatically reduced by product gases through thermal decomposition of dodecane, and then $\mathrm{NiAl}_{2} \mathrm{O}_{4}$ was completely reduced to metallic nickel by the $\mathrm{CO}$ and $\mathrm{H}_{2}$ gases produced during the reaction. Additionally, catalytic performance of auto-reduced NA10-PM were investigated at varying steam/carbon molar ratio $(\mathrm{S} / \mathrm{C})$ and oxygen/carbon molar ratio $\left(\mathrm{O}_{2} / \mathrm{C}\right)$ in order to determine the optimum conditions of the auto-thermal reforming reaction. The conversion of dodecane over auto-reduced NA10-PM catalyst was remarkable (93\%) and increased during the reaction, under conditions of $\mathrm{S} / \mathrm{C}=1.23, \mathrm{O}_{2} / \mathrm{C}=0.25$, and gas hourly space velocity of $12,000 \mathrm{~h}^{-1}$ at $750{ }^{\circ} \mathrm{C}$. The results of this study demonstrated that the auto-reduced NA10-PM catalyst was applied successfully for auto-thermal reforming of dodecane.
\end{abstract}

Keywords: auto-thermal reforming; nickel; thermal decomposition; auto-reduction; polymer-modified incipient method

\section{Introduction}

Fuel cells show higher energy efficiencies than internal combustion engines. The feed gas generally used in fuel cells is $\mathrm{H}_{2}$, which restricts the applications of fuel cells. Although the use of hydrogen is an interesting alternative to increase fuel economy, it is difficult to store hydrogen in vehicle storage tanks because of the absence of suitable infrastructure for hydrogen storage. Fuel cell-based auxiliary power units (APU) take advantage of the fact that liquid hydrocarbons such as gasoline, kerosene, and diesel may be converted into hydrogen. APU systems also offer other advantages such as slightly higher efficiencies and reduced emission of contaminants. Moreover, it is easy to store and transport liquid fossil fuels such as diesel, gasoline, and liquid hydrocarbons compared to hydrogen 
and methane. In particular, diesel oil is widely used in the industry and is transported via boilers, trucks, and ships. However, fuel reforming technology is needed to enable the use of diesel in fuel cells [1-3]. The commonly used technologies for converting diesel oil into $\mathrm{H}_{2}$ and $\mathrm{CO}$ in fuel cell-based APUs are steam reforming (SR), partial oxidation reforming (POx), and auto-thermal reforming (ATR). The corresponding reactions are as follows:

Steam reforming (SR): $\mathrm{C}_{\mathrm{n}} \mathrm{H}_{\mathrm{m}}+\mathrm{nH}_{2} \mathrm{O} \leftrightarrow \mathrm{nCO}+(\mathrm{n}+\mathrm{m} / 2) \mathrm{H}_{2}$

Partial oxidation (POx): $\mathrm{C}_{\mathrm{n}} \mathrm{H}_{\mathrm{m}}+(\mathrm{n} / 2) \mathrm{O}_{2} \leftrightarrow \mathrm{nCO}+(\mathrm{m} / 2) \mathrm{H}_{2}$

Auto thermal reforming (ATR): $\mathrm{C}_{\mathrm{n}} \mathrm{H}_{\mathrm{m}}+(\mathrm{n} / 4) \mathrm{O}_{2}+(\mathrm{n} / 2) \mathrm{H}_{2} \mathrm{O} \leftrightarrow \mathrm{nCO}+(\mathrm{n}+\mathrm{m}) / 2 \mathrm{H}_{2}$

Exothermic POx requires less energy than endothermic SR in the production of hydrogen from liquid hydrocarbons. ATR, in which the highly endothermic SR is combined with the exothermic POx, is the preferred technology because of optimum reforming and energy efficiencies, and short start-up time. Moreover, ATR of liquid hydrocarbons is thermally more stable than SR. The exothermic water gas shift (WGS, $\mathrm{CO}+\mathrm{H}_{2} \mathrm{O}=\mathrm{CO}_{2}+\mathrm{H}_{2}$ ) reaction can occur in the presence of $\mathrm{CO}$ and $\mathrm{H}_{2} \mathrm{O}$ [4-7]. Many researchers have made an effort to synthesize compatible catalysts for use in diesel reforming [8,9]. Ethanol reforming for hydrogen production was conducted over several catalysts $\left(\mathrm{Ni} / \mathrm{CeO}_{2}-\mathrm{SiO}_{2}, \mathrm{Pt} / \mathrm{CeO}_{2}-\mathrm{SiO}_{2}, \mathrm{Pt}-\mathrm{Ni} / \mathrm{CeO}_{2}-\mathrm{SiO}_{2}\right.$, and $\left.\mathrm{Ni} / \mathrm{CeO}_{2}\right)$ [10,11]. Precious metal-based $(\mathrm{Pt}, \mathrm{Pd}$, $\mathrm{Rh}$, and $\mathrm{Ru}$ ) catalysts exhibit better resistance to carbon deposition and sulfur poisoning than Ni-based catalysts. Perovskite-type oxides $\left(\mathrm{ABO}_{3}\right)$ have also been considered as reforming catalysts in solid oxide fuel cells (SOFC), where A is lanthanum and $\mathrm{B}$ is a first-row transition metal ( $\mathrm{Ni}, \mathrm{Co}, \mathrm{Fe}, \mathrm{Mn}$, or $\mathrm{Cr}$ ) [12]. Ni-based catalysts have been studied extensively using various methods and under different conditions in the production of hydrogen. Mesoporous nickel-alumina catalysts have been used in hydrogen production by the SR of liquefied natural gas (LNG) [13]. The performances of Ni-based monolith reforming catalysts for the SR, POx, and ATR of n-dodecane have also been evaluated [14-16]. In particular, the catalytic properties and carbon-decomposition resistance of nickel-alumina catalysts have been studied in the SR reactions of various hydrocarbon fuels [17-21]. Nickel-alumina-based catalysts are usually prepared by impregnation or co-precipitation, with the former method being simpler than the latter. However, the efficiencies of the catalysts prepared by impregnation were found to be lower than those of the catalysts prepared by co-precipitation. To complement the shortcomings of the preparation method, polymer-modified incipient method (PM method) was proposed [22,23].

Previous reports showed that the PM method is simple and the thus-synthesized catalysts exhibit high efficiency. However, this catalyst was not studied in detail under different ATR conditions. In this study, the catalytic performances of auto-reduced catalysts were compared with those of the catalyst reduced by hydrogen gas. Conventionally, oxidized catalysts are reduced by $\mathrm{H}_{2}$ gas and then used for reactions. The auto-reduction process is proposed to integrate both catalyst reduction and reaction [24-27]. The catalytic performances of the catalysts were tested after they were auto-reduced by product gas obtained from thermal decomposition of $n$-dodecane at the reaction temperature. Furthermore, the ATR performances of the auto-reduced catalysts were investigated as a function of various reaction parameters such as steam/carbon molar ratio $(\mathrm{S} / \mathrm{C})$, and oxygen/carbon molar ratio $\left(\mathrm{O}_{2} / \mathrm{C}\right)$. The catalysts were characterized using $\mathrm{H}_{2}$ and $\mathrm{CO}$ temperature-programed reduction (TPR), Brunauer-Emmett-Teller (BET) surface area analysis, and X-ray diffraction (XRD) analysis.

\section{Results and Discussion}

\subsection{Catalytic Performance Comparison of NA10-PM with Various Catalysts}

Dodecane conversion and selectivity of $\mathrm{Ni}$-Al catalyst prepared by polymer-modified incipient method (NA10-PM) were tested and compared with those of other metal impregnated catalysts on alumina support such as Ni (NA10-IM), Ru (RuA5-IM), and Rh (RhA5-IM). All the catalysts were typically reduced by $10 \% \mathrm{H}_{2}$ at $750{ }^{\circ} \mathrm{C}$ for $2 \mathrm{~h}$. Figure 1 shows the dodecane conversions and initial selectivity under $\mathrm{S} / \mathrm{C}$ ratio $=1.23, \mathrm{O}_{2} / \mathrm{C}$ ratio $=0.25$, and gas hourly space velocity $(\mathrm{GHSV})=12,000 \mathrm{~h}^{-1}$ 
at $700{ }^{\circ} \mathrm{C}$. The dodecane conversions with NA10-IM, NA10-PM, and RhA5-IM were $72.5 \%, 85.0 \%$, and $85.8 \%$, respectively, over a period of $300 \mathrm{~min}$. In contrast, dodecane conversion with RuA5-IM was $58.5 \%$ initially and then gradually decreased to $45 \%$ as the reaction progressed. The product selectivity using NA10-PM was about $67.2 \% \mathrm{H}_{2}, 19.6 \% \mathrm{CO}, 11.6 \% \mathrm{CO}_{2}$, and $1.48 \% \mathrm{CH}_{4}$. For the NA10-IM catalyst, that was about $68.12 \% \mathrm{H}_{2}, 18.9 \% \mathrm{CO}, 11.8 \% \mathrm{CO}_{2}$, and $1.14 \% \mathrm{CH}_{4}$. Although the product selectivity showed similar values, the dodecane conversion using the NA10-PM catalyst was higher than that obtained with NA10-IM, in agreement with a previous report [22,23]. In addition, NA10-PM exhibited a similar dodecane conversion (85.8\%) as RhA5-IM. These results are excellent from an industrial point of view because the price of nickel is much less than that of rhodium, and there are more nickel reserves.
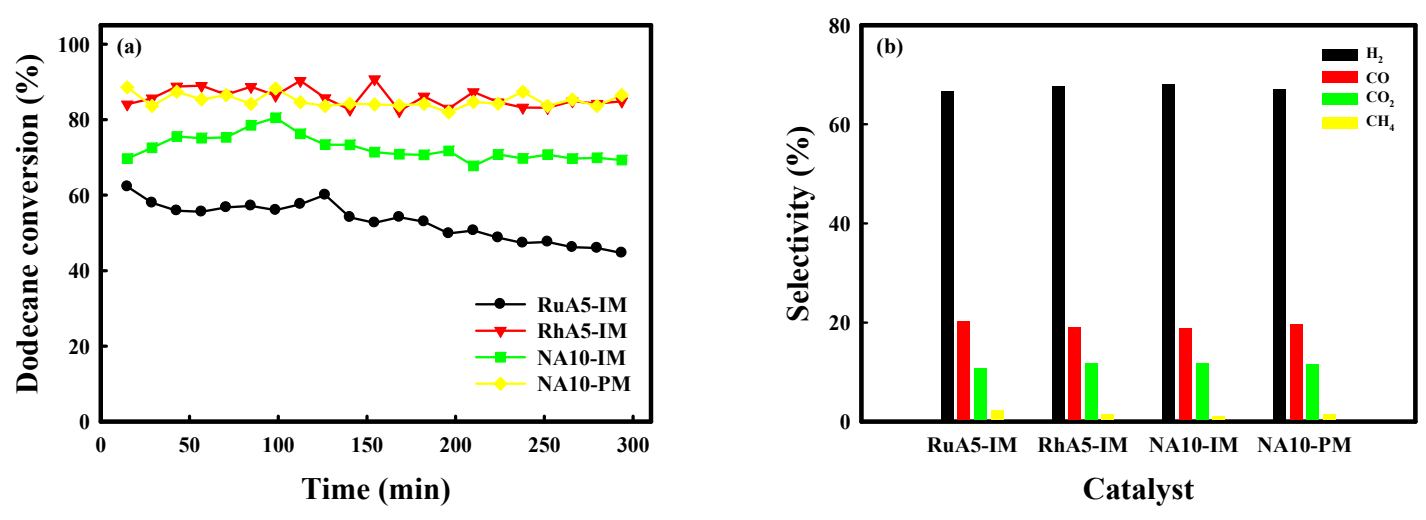

Figure 1. (a) Dodecane conversion and (b) initial selectivity of various auto-thermal catalysts under $\mathrm{S} / \mathrm{C}=1.23$ and $\mathrm{O}_{2} / \mathrm{C}=0.25$ at $700{ }^{\circ} \mathrm{C}$.

\subsection{Characterization}

Conventionally, oxidized catalysts are reduced by $\mathrm{H}_{2}$ gas and then used for reactions. In the auto-reduction process, the oxidized catalysts are initially reduced by heat, photochemical radiation, and a reductant obtained from the thermal decomposition of feedstock [24-27]. In this study, the oxidized catalysts were reduced by the reductant generated from the thermal decomposition of n-dodecane. Dodecane was thermally decomposed to $\mathrm{H}_{2}, \mathrm{CO}, \mathrm{CO}_{2}$, and $\mathrm{CH}_{4}$, under $\mathrm{S} / \mathrm{C}=1.23$ and $\mathrm{O}_{2} / \mathrm{C}=0.25$ at $750{ }^{\circ} \mathrm{C}$ (Supplementary Materials Figure S1). Temperature-programmed reduction (TPR) was used to investigate the reducibility of the Ni species on the NA10-PM catalyst under the conditions of $\mathrm{H}_{2}$ reduction and auto-reduction (simulated $\mathrm{CO}$ and $\mathrm{H}_{2}$ gases). Figure 2 shows the TPR profiles obtained under the conditions of (a) $\mathrm{H}_{2}$ reduction and (b) auto-reduction of the NA10-PM catalyst. Both TPR profiles showed two groups of peaks. The low-temperature peaks were attributed to the reduction of $\mathrm{NiO}$, indicating minimal or no interaction with the alumina supports $(\mathrm{NiO}$ and $\mathrm{NiO}-\mathrm{Al}_{2} \mathrm{O}_{3}$ ), whereas the high-temperature peaks may be attributed to the strong interaction of $\mathrm{NiO}$ and the alumina support $\left(\mathrm{NiAl}_{2} \mathrm{O}_{4}\right)$. It was found that the reduction of $\mathrm{NiO}$ and $\mathrm{NiAl}_{2} \mathrm{O}_{4}$ occurred at lower temperatures under the auto-reduction conditions $\left(220\right.$ and $750{ }^{\circ} \mathrm{C}$, respectively), compared to the $\mathrm{H}_{2}$-reduction conditions ( 250 and $810^{\circ} \mathrm{C}$, respectively). Thus, it was concluded that the presence of $\mathrm{CO}$ with $\mathrm{H}_{2}$ (auto-reduction condition) improved the reducibility of $\mathrm{NiO}$ and $\mathrm{NiAl}_{2} \mathrm{O}_{4}$, in agreement with a previous report [28].

To elucidate the effect of auto-reduction on the reducibility of NA10-PM, nitrogen adsorption-desorption isotherms and XRD patterns of the fresh and reduced catalysts were investigated. The nitrogen adsorption-desorption isotherms and the textural properties of fresh and reduced NA10-PM catalyst are shown in Figure 3a and listed in Table 1, respectively. Under the typical $\mathrm{H}_{2}$ reduction conditions, NA10-PM was analyzed after reduction using $10 \% \mathrm{H}_{2}$ at $750{ }^{\circ} \mathrm{C}$ for $2 \mathrm{~h}$. Under the auto-reduction conditions, the catalyst was analyzed after reduction by product gases obtained from the thermal decomposition of $n$-dodecane, under feed gas conditions of $S / C=1.23$ 
and $\mathrm{O}_{2} / \mathrm{C}=0.25$ at $750{ }^{\circ} \mathrm{C}$ for $2 \mathrm{~h}$. As shown in Figure 3a, the fresh, $\mathrm{H}_{2}$-reduced, and auto-reduced NA10-PM catalysts exhibited type IV (a) isotherms, which indicates some steep mesopore condensation at $\mathrm{P} / \mathrm{P}_{0}=0.7-0.8$ and an almost flat region at $\mathrm{P} / \mathrm{P}_{0}>0.8$. The auto-reduced catalysts also showed type IV (a) nitrogen adsorption-desorption isotherms; the volume of adsorbed nitrogen gas increased with increasing temperature. Additionally, the volume of adsorbed nitrogen for auto-reduced catalysts at $750{ }^{\circ} \mathrm{C}$ is higher than that for typical $\mathrm{H}_{2}$-reduced catalysts. As listed in Table 1, for the fresh catalysts, textural properties such as BET surface area, pore volume, and average pore size of the NA10-PM catalyst were $28.1 \mathrm{~m}^{2} / \mathrm{g}, 0.04 \mathrm{~cm}^{3} / \mathrm{g}$, and $3.8 \mathrm{~nm}$, respectively. For $\mathrm{H}_{2}$-reduction, textural properties such as BET surface area, pore volume, and average pore size were $78.1 \mathrm{~m}^{2} / \mathrm{g}, 0.06 \mathrm{~cm}^{3} / \mathrm{g}$, and $3.8 \mathrm{~nm}$, respectively. On the other hand, auto-reduced catalysts showed that textural properties such as BET surface area, pore volume, and average pore size were $96.6 \mathrm{~m}^{2} / \mathrm{g}, 0.12 \mathrm{~cm}^{3} / \mathrm{g}$, and $4.1 \mathrm{~nm}$, respectively. Based on these results, it is expected that the NA10-PM catalyst was more reduced under auto-reduction condition. Figure $3 \mathrm{~b}$ showed the XRD patterns of fresh and pre-treated NA10-PM activated by typical $\mathrm{H}_{2}$ reduction and auto-reduction. As shown in Figure 3b, fresh NA10-PM exhibited three main peaks, which overlapped with the two main peaks of $-\mathrm{Al}_{2} \mathrm{O}_{3}$ and $\mathrm{NiAl}_{2} \mathrm{O}_{4}$ alloy structures, but no diffraction peaks corresponding to bulk $\mathrm{NiO}$. It was revealed that diffraction peak of $-\mathrm{Al}_{2} \mathrm{O}_{3}$ at $66.84^{\circ}$ shifted to a lower diffraction angle, representing lattice expansion of $-\mathrm{Al}_{2} \mathrm{O}_{3}$ caused by the incorporation of $\mathrm{Ni}^{2+}$ ions into $-\mathrm{Al}_{2} \mathrm{O}_{3}\left(\mathrm{NiAl}_{2} \mathrm{O}_{4}\right)$ [29-32]. Therefore, the peak at $66.18^{\circ}$ indicated that the $\mathrm{Ni}$ components were alloyed with $-\mathrm{Al}_{2} \mathrm{O}_{3}$ during preparation. The $\mathrm{NiAl}_{2} \mathrm{O}_{4}$ phase was inactive for reforming reaction, but was used as precursor materials, leading to catalysts with desired properties (smaller particle size and higher dispersion of $\mathrm{Ni}$ species). After typical $\mathrm{H}_{2}$-reduction and auto-reduction for $2 \mathrm{~h}$, diffraction peak for metallic nickel was observed, and the diffraction peak for $\mathrm{NiAl}_{2} \mathrm{O}_{4}$ was shifted to the peak for $-\mathrm{Al}_{2} \mathrm{O}_{3}$ after reduction, indicating a portion of $\mathrm{NiAl}_{2} \mathrm{O}_{4}$ was reduced to metallic nickel. After auto-reduction for $2 \mathrm{~h}$, more distinctive peak for metallic nickel was observed, compared to the catalyst after $\mathrm{H}_{2}$-reduction. Moreover, it was found that the intensity of metallic nickel increased with the increasing temperature, and the two angle for $\mathrm{NiAl}_{2} \mathrm{O}_{4}$ shifted farther to the peak for $-\mathrm{Al}_{2} \mathrm{O}_{3}$ (Supplementary Materials Figure S2b). It was found that metallic nickel is more activated by auto-reduction with increasing temperature, under feed gas conditions. These results are in good agreement with the TPR profiles, and nitrogen adsorption-desorption isotherms. Therefore, it can be concluded that nickel species in NA10-PM catalyst was more reduced by an auto-reduction condition, compared to typical $\mathrm{H}_{2}$-reduction.

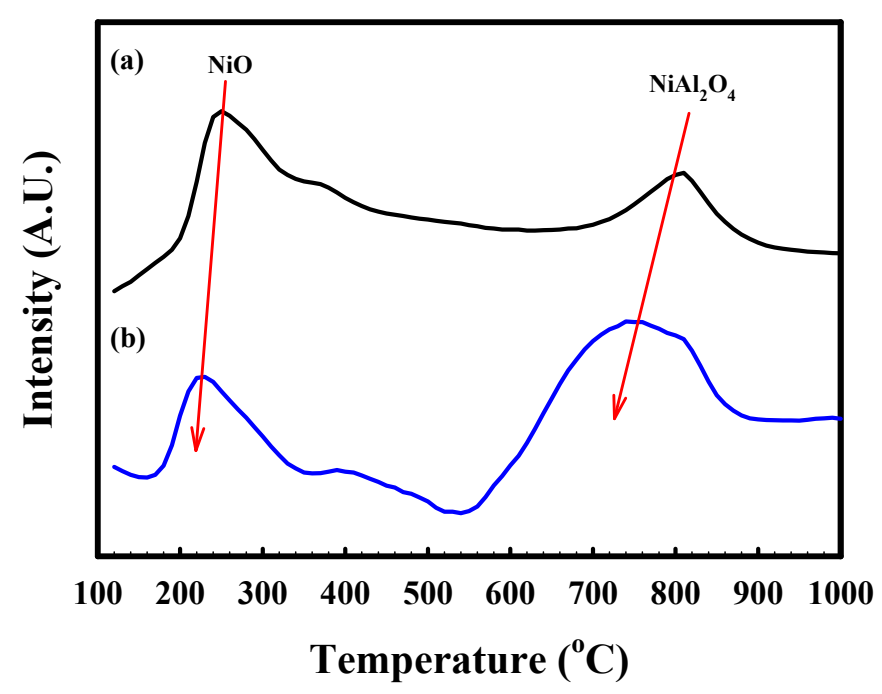

Figure 2. Temperature-programed reduction (TPR) profiles of the NA10-PM catalyst under (a) $\mathrm{H}_{2}$-reduction and (b) auto-reduction condition. 


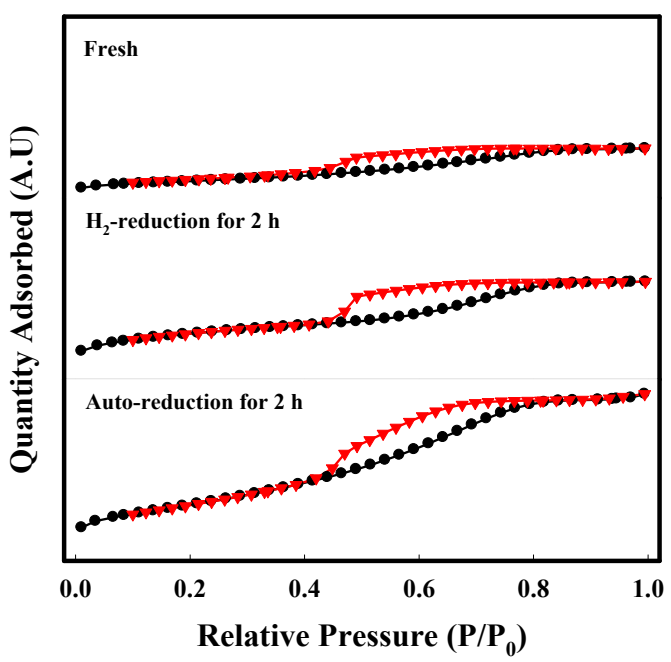

(a)

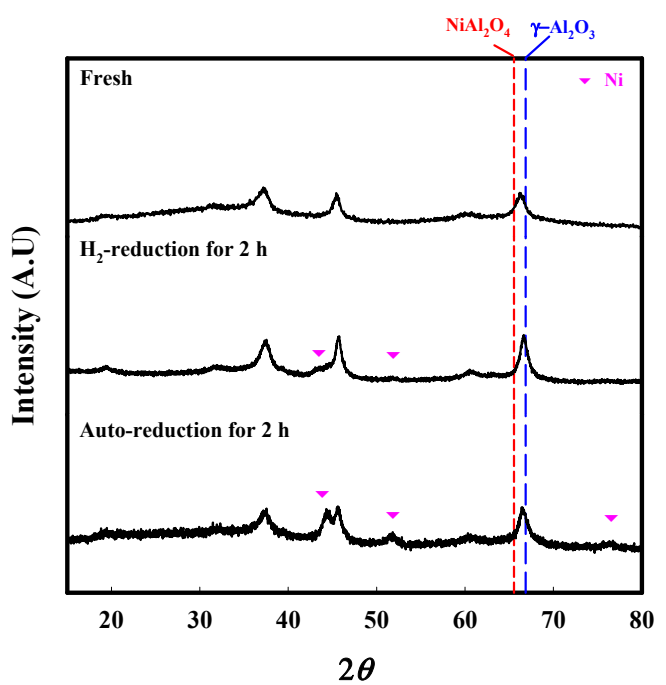

(b)

Figure 3. (a) Nitrogen adsorption-desorption isotherms and (b) XRD patterns of the fresh and reduced NA10-PM, activated by conventional $\mathrm{H}_{2}$ reduction and by auto-reduction at $750{ }^{\circ} \mathrm{C}$ for $2 \mathrm{~h}$.

Table 1. Textural properties of fresh and reduced NA10-PM catalyst activated by conventional $\mathrm{H}_{2}$-reduction and by auto-reduction at $750{ }^{\circ} \mathrm{C}$ for $2 \mathrm{~h}$.

\begin{tabular}{cccc}
\hline & BET Surface Area $\left(\mathbf{m}^{2} / \mathbf{g}\right)$ & Pore Volume $\left(\mathbf{c m}^{3} / \mathbf{g}\right)$ & Average Pore Size $(\mathbf{n m})$ \\
\hline Fresh & 28.1 & 0.04 & 3.8 \\
$\mathrm{H}_{2}$-reduction & 78.1 & 0.06 & 3.8 \\
Auto-reduction & 96.6 & 0.12 & 4.1 \\
\hline
\end{tabular}

\subsection{Catalytic Performance of Auto-Reduced NA10-PM Catalyst}

Figure 4 shows the dodecane conversions and initial selectivity of NA10-PM catalyst reduced by typical $\mathrm{H}_{2}$ reduction and auto-reduction under $\mathrm{S} / \mathrm{C}=1.23, \mathrm{O}_{2} / \mathrm{C}=0.25$, and GHSV $=12,000 \mathrm{~h}^{-1}$ at $750{ }^{\circ} \mathrm{C}$. As shown in Figure $4 \mathrm{a}$, the initial dodecane conversions using $\mathrm{H}_{2}$-reduced NA10-PM at 650, 700 , and $750{ }^{\circ} \mathrm{C}$ were approximately $82 \%, 85 \%$, and $83 \%$, respectively. While the dodecane conversions at $650{ }^{\circ} \mathrm{C}$ decreased as reaction progressed, those at 700 and $750{ }^{\circ} \mathrm{C}$ were maintained for $5 \mathrm{~h}$. As shown in Figure $4 \mathrm{~b}$, the concentration of $\mathrm{H}_{2}$ gas showed a similar value of approximately $67 \%$ regardless of the reaction temperature. On the other hand, the concentration of $\mathrm{CO}$ increased, and that of $\mathrm{CO}_{2}$ and $\mathrm{CH}_{4}$ decreased with the rise of reaction temperature. The reason for this concentration change is that the exothermic WGS and methanation reaction decreased with the rise in reaction temperature. As shown in Figure 5a, the initial dodecane conversions of the auto-reduced catalysts at 650, 700, and $750{ }^{\circ} \mathrm{C}$ were approximately $75 \%, 90 \%$, and $93 \%$, respectively. However, the dodecane conversions decreased at 650 and $700{ }^{\circ} \mathrm{C}$ as the reaction progressed. It was found that the dodecane conversion of NA10-PM increased with the reaction temperature. This is because the nickel species were not fully reduced by auto-reduction at relatively lower temperatures, and therefore, lower dodecane conversions and catalytic deactivation were observed. As shown in Figure 5b, the initial selectivity of $\mathrm{H}_{2}$ increased, and that of $\mathrm{CO}, \mathrm{CO}_{2}$, and $\mathrm{CH}_{4}$ decreased with increasing reaction temperature. In particular, auto-reduced NA10-PM at $750{ }^{\circ} \mathrm{C}$ showed a higher dodecane conversion and similar product gas distribution than that of $\mathrm{H}_{2}$-reduced NA10-PM at $750{ }^{\circ} \mathrm{C}$. 

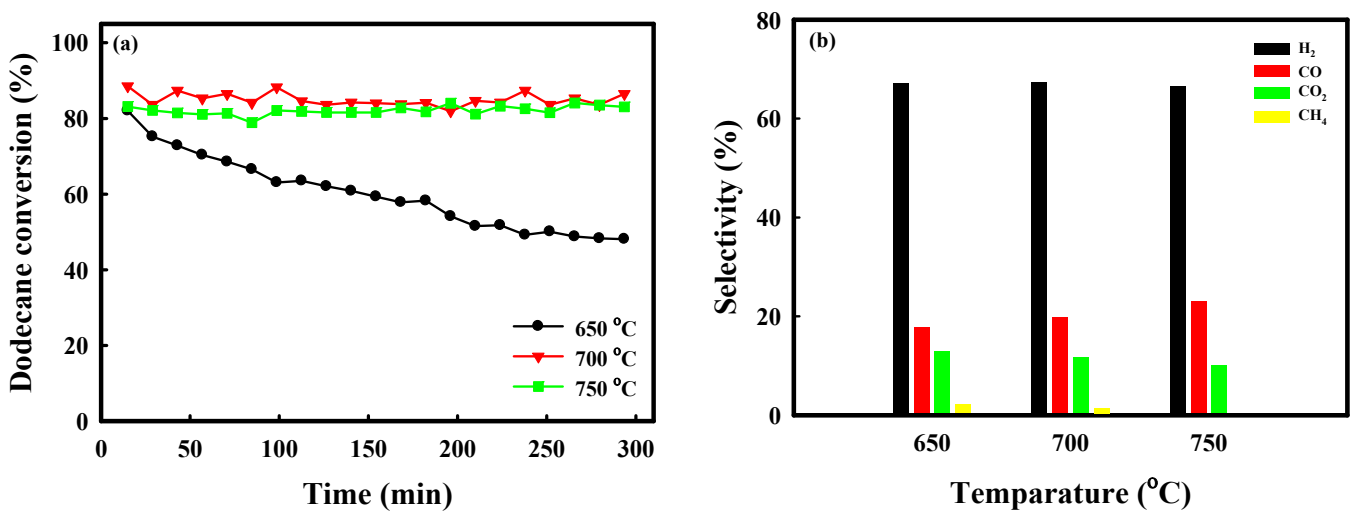

Figure 4. (a) Dodecane conversion and (b) initial selectivity of $\mathrm{H}_{2}$-reduced and NA10-PM at various temperatures $\left(650,700\right.$, and $\left.750{ }^{\circ} \mathrm{C}\right)$ under $\mathrm{S} / \mathrm{C}=1.23$ and $\mathrm{O}_{2} / \mathrm{C}=0.25$.
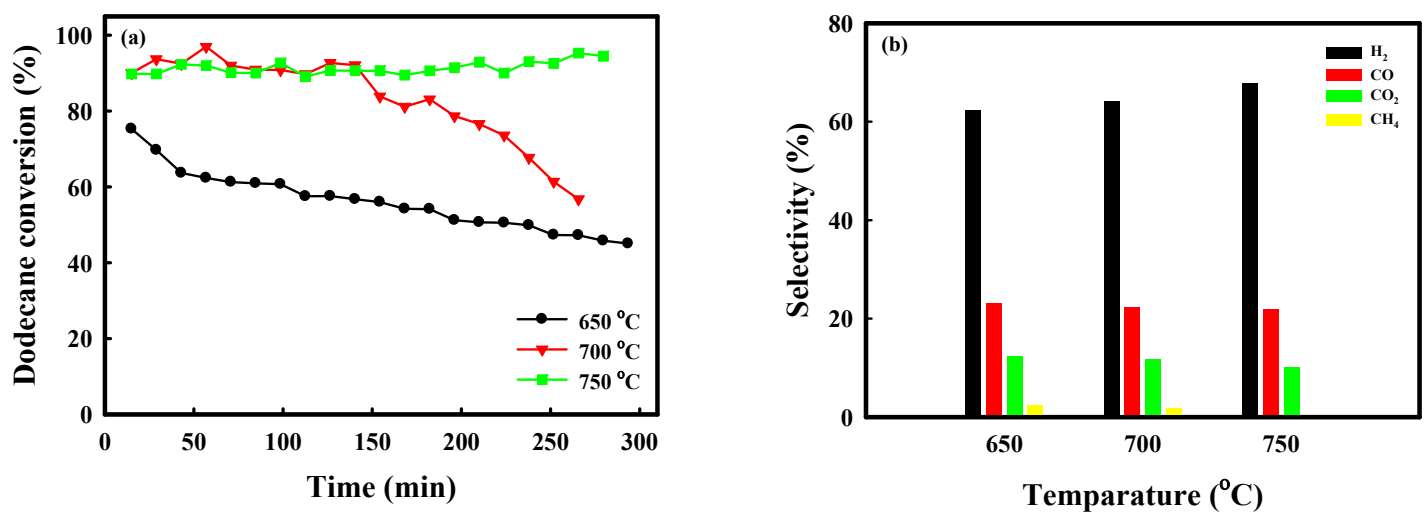

Figure 5. (a) Dodecane conversion and (b) initial selectivity of auto-reduced and NA10-PM at various temperatures $\left(650,700\right.$, and $\left.750^{\circ} \mathrm{C}\right)$ under $\mathrm{S} / \mathrm{C}=1.23$ and $\mathrm{O}_{2} / \mathrm{C}=0.25$.

To investigate the effect of $\mathrm{S} / \mathrm{C}$ ratio on catalytic performance, the auto-reduced NA10-PM catalyst was tested at $\mathrm{S} / \mathrm{C}=0.5,1.23,2.0$, and $2.75, \mathrm{O}_{2} / \mathrm{C}=0.25$, and GHSV $=12,000 \mathrm{~h}^{-1}$ at $750{ }^{\circ} \mathrm{C}$. As shown in Figure 6 , at $S / C=0.5$, the dodecane conversion was approximately $80 \%$ during the initial reaction period, and then gradually decreased. However, above $S / C=2.0$, the dodecane conversion was maintained at above $95 \%$ for $5 \mathrm{~h}$. In addition, the concentration of $\mathrm{CO}$ gas at $\mathrm{S} / \mathrm{C}=0.5$ was the highest compared to that at other S/C ratios, and it decreased with the increasing $\mathrm{S} / \mathrm{C}$ ratios. The initial selectivity of $\mathrm{H}_{2}$ and $\mathrm{CO}_{2}$ showed an opposite trend to that of $\mathrm{CO}$. These results are attributed to the fact that an increase in steam ratio was because of the WGS reaction, leading to an increase in the selectivity of $\mathrm{H}_{2}$ and $\mathrm{CO}_{2}$. The composition of dry product gases at increased $\mathrm{S} / \mathrm{C}$ ratios resembled the conventional thermodynamic equilibrium performance as reported previously [33]. Figure 7 shows the XRD patterns of the auto-reduced NA10-PM at different $\mathrm{S} / \mathrm{C}$ ratios $\left(0.5,1.23\right.$, and 2.75), $\mathrm{O}_{2} / \mathrm{C}=0.25$, and GHSV $=12,000 \mathrm{~h}^{-1}$ at $750{ }^{\circ} \mathrm{C}$. Metallic nickel increased with the increase in S/C ratios. With S/C $=2.75, \mathrm{NiAl}_{2} \mathrm{O}_{4}$ was completely transformed to metallic nickel and the two angle of $\mathrm{NiAl}_{2} \mathrm{O}_{4}$ was completely shifted to $-\mathrm{Al}_{2} \mathrm{O}_{3}$. Considering the amount of steam in the feed, the dodecane conversion, and the selectivity of $\mathrm{H}_{2}$ and $\mathrm{CO}$ gases, $\mathrm{S} / \mathrm{C}=1.23$ was selected as the optimal condition. 

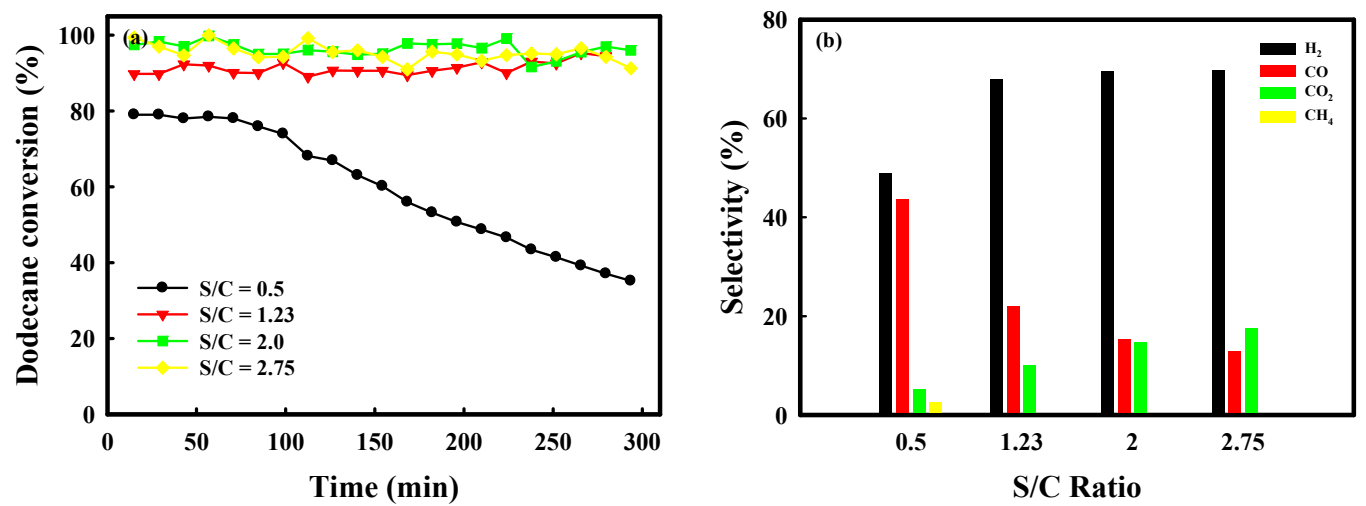

Figure 6. Effect of S/C ratio on catalytic performance: (a) Dodecane conversion and (b) initial selectivity of auto-reduced NA10-PM catalyst under $\mathrm{O}_{2} / \mathrm{C}=0.25$, and GHSV $=12,000 \mathrm{~h}^{-1}$ at $750{ }^{\circ} \mathrm{C}$.

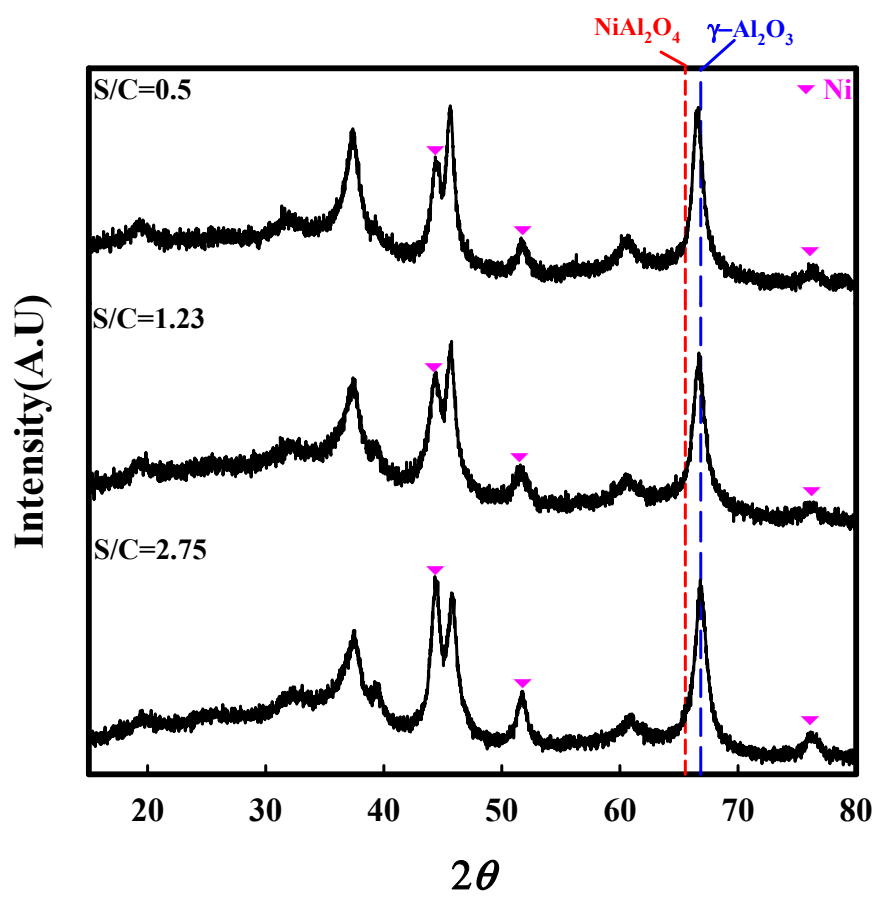

Figure 7. XRD patterns of auto-reduced NA10-PM catalyst after reaction at various $\mathrm{S} / \mathrm{C}$ ratios for $5 \mathrm{~h}$ under $\mathrm{O}_{2} / \mathrm{C}=0.25$, and GHSV $=12,000 \mathrm{~h}^{-1}$ at $750{ }^{\circ} \mathrm{C}$.

Figure 8 shows the dodecane conversions and selectivity attained with the auto-reduced NA10-PM catalyst under various $\mathrm{O}_{2} / \mathrm{C}$ ratios $(0.05,0.15,0.25$, and 0.35$), \mathrm{S} / \mathrm{C}=1.23$, and GHSV $=12,000 \mathrm{~h}^{-1}$ at $750{ }^{\circ} \mathrm{C}$, conducted in order to elucidate the effect of the $\mathrm{O}_{2} / \mathrm{C}$ ratio on catalytic performance. Under all conditions, the dodecane conversion was above $85 \%$ during the initial reaction period. However, the conversions decreased with increasing reaction times, except for $\mathrm{O}_{2} / \mathrm{C}=0.25$. The selectivity of $\mathrm{CO}, \mathrm{H}_{2}$, and $\mathrm{CH}_{4}$ among the dry gases decreased slightly with the increase in $\mathrm{O}_{2} / \mathrm{C}$ ratio, while the concentration of $\mathrm{CO}_{2}$ increased. In particular, the dodecane conversion was only maintained at $\mathrm{O}_{2} / \mathrm{C}=0.25$. To investigate this phenomenon, the XRD patterns are depicted in Figure 9. It was found that the peak intensity of the two angle assigned to metallic nickel after the reaction at $\mathrm{O}_{2} / \mathrm{C}=0.05$ and 0.35 was lower than that at $\mathrm{O}_{2} / \mathrm{C}=0.25$. With a low $\mathrm{O}_{2}$ concentration, the amount of heat emitted by partial oxidation decreased, which caused the dodecane conversion to gradually decrease because of insufficient heat produced in the steam reforming of dodecane. Moreover, this phenomenon could be further accelerated because the catalyst was not sufficiently reduced, as shown by XRD. On the contrary, under high $\mathrm{O}_{2}$ concentrations, although the dodecane 
conversion was relatively higher during the initial reaction period, the auto-reduced NA10-PM catalyst was suddenly deactivated. It could only be inferred that the oxidation reaction of reduced metallic nickel after the initial reaction by unreacted oxygen during reforming was more dominant than the reduction of $\mathrm{NiAl}_{2} \mathrm{O}_{4}$ by product gases $\left(\mathrm{CO}\right.$ and $\left.\mathrm{H}_{2}\right)$. The $\mathrm{O}_{2}$ amount in the feed was more important in maintaining the dodecane conversion of the auto-reduced NA10-PM catalyst at the S/C ratio of 1.23 , rather than the amount of steam. The optimum conditions to maintain the maximum catalytic performance on the auto-reduced NA10-PM catalyst were $\mathrm{S} / \mathrm{C}=1.23$ and $\mathrm{O}_{2} / \mathrm{C}=0.25$ at $750{ }^{\circ} \mathrm{C}$.
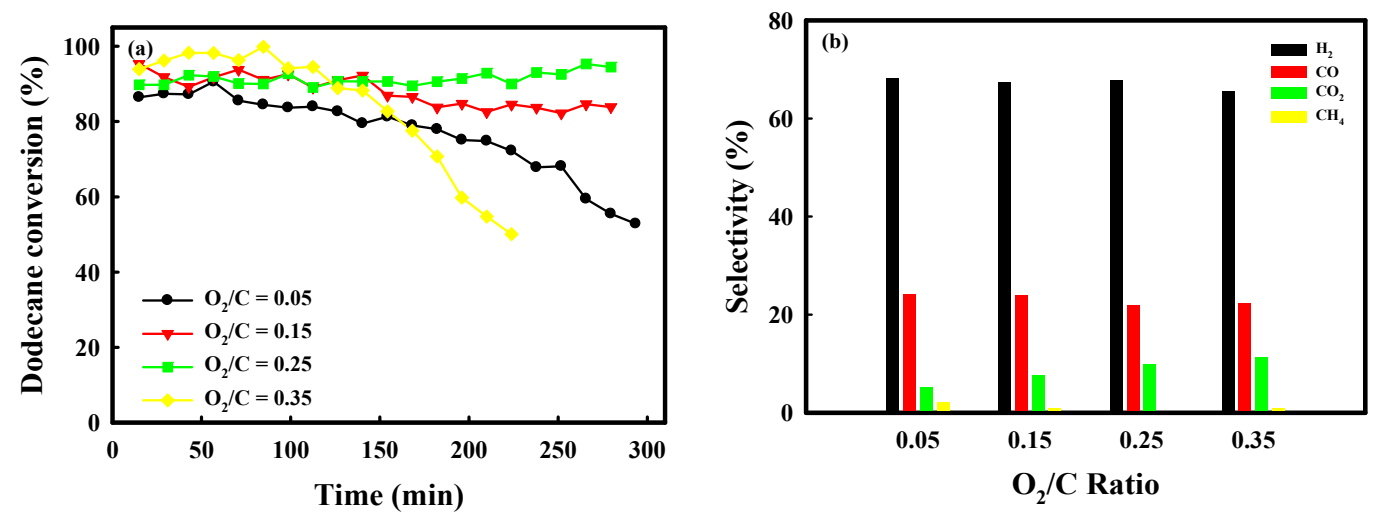

Figure 8. Effect of $\mathrm{O}_{2} / \mathrm{C}$ ratio on catalytic performance: (a) Dodecane conversion and (b) initial selectivity of auto-reduced NA10-PM catalyst under $\mathrm{S} / \mathrm{C}=1.23$, and GHSV $=12,000 \mathrm{~h}^{-1}$ at $750{ }^{\circ} \mathrm{C}$.

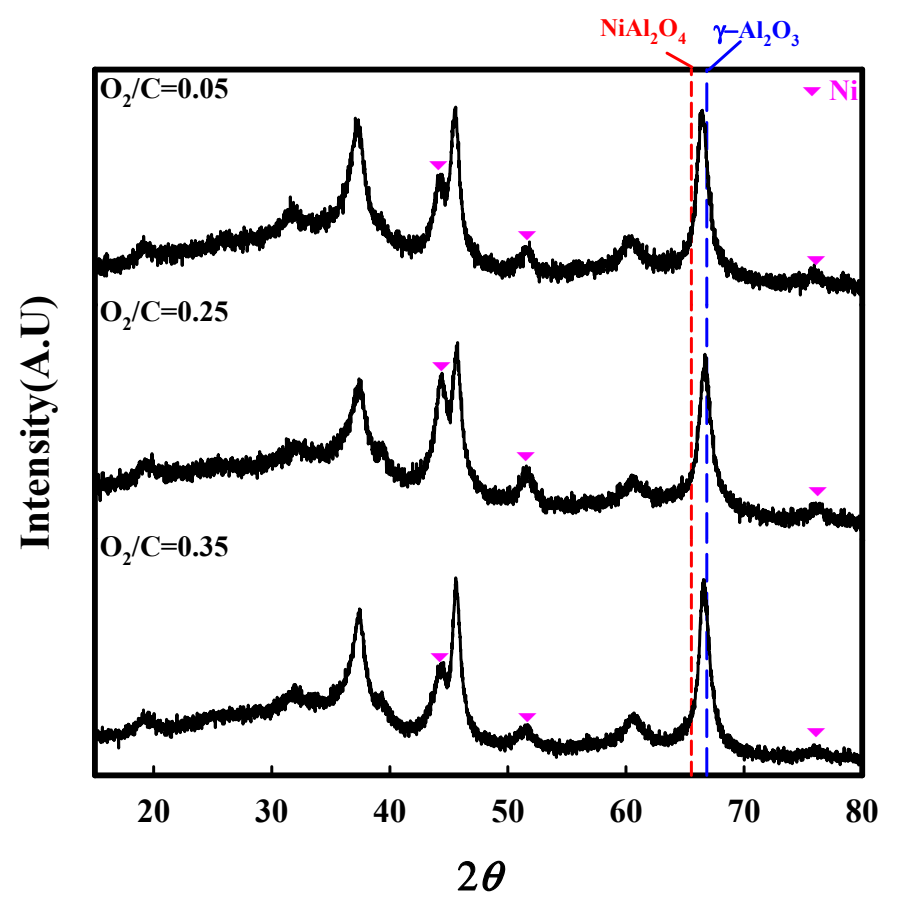

Figure 9. XRD patterns of auto-reduced NA10-PM catalyst after reaction at various $\mathrm{O}_{2} / \mathrm{C}$ ratios for $5 \mathrm{~h}$ under $\mathrm{S} / \mathrm{C}=1.23$, and $\mathrm{GHSV}=12,000 \mathrm{~h}^{-1}$ at $750{ }^{\circ} \mathrm{C}$.

To evaluate catalytic stability, dodecane conversion obtained using auto-reduced NA10-PM catalyst was compared with those obtained using $\mathrm{H}_{2}$-reduced NA10-IM and NA10-PM catalysts under conditions of $\mathrm{S} / \mathrm{C}=1.23, \mathrm{O}_{2} / \mathrm{C}=0.25$, and GHSV $=12,000 \mathrm{~h}^{-1}$ at $750{ }^{\circ} \mathrm{C}$ (Figure 10). The dodecane conversion by $\mathrm{H}_{2}$-reduced NA10-IM catalyst was initially increased slightly up to $75 \%$ and was maintained at that value, followed by a slow decrease. On the other hand, dodecane conversion by $\mathrm{H}_{2}$-reduced NA10-PM was maintained at $83 \%$ for $5 \mathrm{~h}$ and subsequently 
decreased slightly to $76 \%$. On the other hand, the dodecane conversion by auto-reduced NA10-PM was initially $93 \%$, which increased up to $97 \%$ at $17 \mathrm{~h}$. In order to elucidate this phenomenon, the nitrogen adsorption-desorption isotherms and XRD patterns of the auto-reduced NA10-PM catalyst after reaction were analyzed. As shown in Figure 11a, the catalyst showed type V nitrogen adsorption-desorption isotherms after reaction, unlike those of the fresh and reduced catalysts. As shown in Figure 11b, the XRD patterns of the catalyst showed more obvious metallic Ni peak after reaction, compared to that of the auto-reduced catalyst. Based on these results, it was anticipated that the NA10-PM catalyst was auto-reduced by product gases obtained from thermal decomposition of dodecane, and the thus-activated catalyst produced $\mathrm{CO}$ and $\mathrm{H}_{2}$ via the ATR reaction. Moreover, the activated catalyst was further reduced by $\mathrm{CO}$ and $\mathrm{H}_{2}$ during the reaction.

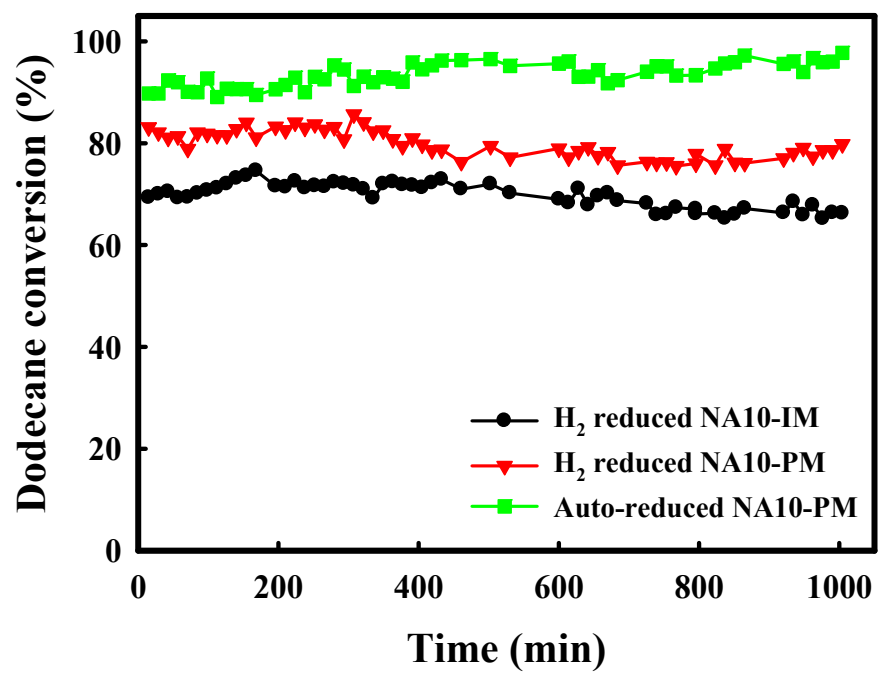

Figure 10. Stability comparison of the auto-reduced NA10-PM catalyst with the $\mathrm{H}_{2}$-reduced NA10-IM and NA10-PM catalysts under conditions of $\mathrm{S} / \mathrm{C}=1.23, \mathrm{O}_{2} / \mathrm{C}=0.25$, and GHSV $=12,000 \mathrm{~h}^{-1}$ at $750{ }^{\circ} \mathrm{C}$.

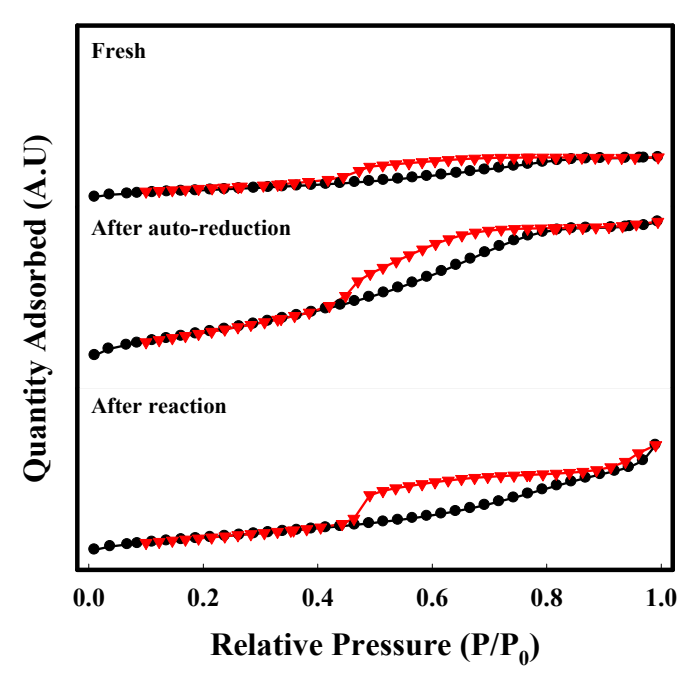

(a)

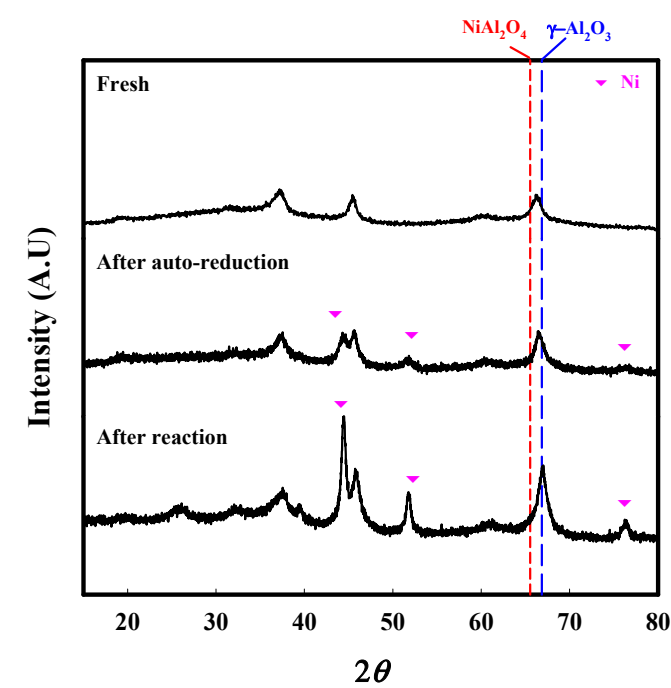

(b)

Figure 11. (a) Nitrogen adsorption-desorption isotherms and (b) XRD patterns of NA10-PM catalyst. 


\section{Materials and Methods}

\subsection{Preparation of Catalysts}

The nickel-alumina catalyst was prepared by the PM method devised for the homogenous

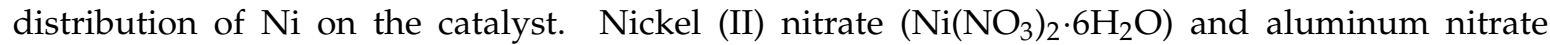
$\left(\mathrm{Al}\left(\mathrm{NO}_{3}\right)_{3} \cdot 9 \mathrm{H}_{2} \mathrm{O}\right)$ were dissolved in $15 \mathrm{~mL}$ of ethylene glycol $(\mathrm{EG})$ by stirring in a beaker at room temperature. Then, $15 \mathrm{~mL}$ of methanol and $1.5 \mathrm{~g}$ of poly(methyl methacrylate) (PMMA) colloidal crystals (MW $=500,000-1,000,000$ ) were added to the EG solution, and the solution was stirred on a hot plate at $100{ }^{\circ} \mathrm{C}$ until the solution was solidified. The obtained powder sample was dried at $250{ }^{\circ} \mathrm{C}$ and calcined at $750{ }^{\circ} \mathrm{C}$ for $4 \mathrm{~h}$ under air; in this procedure, all the solvents and PMMA were removed. The amount of nickel oxide in the catalyst was $10 \mathrm{wt} \%$; thus, this sample was named NA10-PM [22,23]. To compare the catalytic properties of NA10-PM, nickel-alumina (NA10-IM), ruthenium-alumina (RuA5-IM), and rhodium-alumina (RhA5-IM) catalysts were also prepared by the conventional impregnation method (IM). Three separate solutions were prepared by dissolving $\mathrm{Ni}\left(\mathrm{NO}_{3}\right)_{2} \cdot 6 \mathrm{H}_{2} \mathrm{O}$, ruthenium (III) chloride $\left(\mathrm{RuCl}_{3} \cdot x \mathrm{H}_{2} \mathrm{O}\right)$, and rhodium chloride $\left(\mathrm{RhCl}_{3} \cdot x \mathrm{H}_{2} \mathrm{O}\right)$ in water. Then, $-\mathrm{Al}_{2} \mathrm{O}_{3}$ was added to each solution and the mixtures were stirred at room temperature for $1 \mathrm{~h}$. Each suspension was subsequently evaporated via vacuum evaporation. The resulting powders were dried at $250{ }^{\circ} \mathrm{C}$ and calcined at $750{ }^{\circ} \mathrm{C}$ for $4 \mathrm{~h}$ under air. The amount of nickel in the catalyst was $10 \mathrm{wt} \%$, while those of ruthenium and rhodium were $5 \mathrm{wt} \%$ each.

\subsection{Characterization}

The reduction profiles for the NA10-PM $(0.2 \mathrm{~g})$ catalyst were obtained by heating the samples from 120 to $800{ }^{\circ} \mathrm{C}$ at $10^{\circ} \mathrm{C} / \mathrm{min}$ in a fixed-bed reactor under flowing $\mathrm{H}_{2}$ or $\mathrm{CO}$ and $\mathrm{H}_{2}$. The outlet gases from the reactor were analyzed using a thermal conductivity detector (TCD; Donam Systems Inc., Seongnam, Korea). The textural properties such as BET surface area, pore volume, and average pore size were determined using the Micrometrics ASAP 2020 apparatus (Norcross, GA, USA). The crystal structures of the catalysts were analyzed using a $\mathrm{Cu}$ Ka radiation source in a Phillips XPERT X-ray diffraction (XRD) unit at the Korea Basic Science Institute in Daegu. In order to compare the effect of auto-reduction temperature on the reducibility of the catalyst by thermal decomposition of dodecane, the textural properties and XRD patterns of fresh and reduced NA10-PM were investigated. The NA10-PM catalyst was reduced by conventional $\mathrm{H}_{2}$ reduction and auto-reduction. For conventional $\mathrm{H}_{2}$ reduction, NA10-PM was analyzed after reduction under $10 \% \mathrm{H}_{2}$ at $750{ }^{\circ} \mathrm{C}$ for $2 \mathrm{~h}$. For auto-reduction, the catalyst was analyzed after auto-reduction by thermal decomposition of n-dodecane, with feed gas condition of $\mathrm{S} / \mathrm{C}=1.23$ and $\mathrm{O}_{2} / \mathrm{C}=0.25$ at various reaction temperatures $\left(650,700\right.$, and $\left.750{ }^{\circ} \mathrm{C}\right)$ for $2 \mathrm{~h}$.

\subsection{Catalytic Reforming Measurement}

The prepared catalyst $(0.5 \mathrm{~g})$ with a particle size of $150-250 \mu \mathrm{m}$ was packed in the middle of a quartz reactor. The quartz reactor was heated using an electronic furnace and a constant temperature was maintained. The flow rates of gases such as $\mathrm{N}_{2}$ and air were controlled by a mass flow controller. $\mathrm{n}$-Dodecane from Sigma-Aldrich (Yongin, Korea) was selected as a surrogate for diesel fuel because it is regarded to have similar properties. First, $\mathrm{n}$-dodecane and water were injected into the vaporizer using a syringe pump and vaporized at $350{ }^{\circ} \mathrm{C}$. The vapors were carried by $\mathrm{N}_{2}$ into the entrance of the reactor. Condensable liquids were removed before entering the gas chromatograph (GC). The catalytic performances were investigated under various conditions such as varying $\mathrm{S} / \mathrm{C}$ and $\mathrm{O}_{2} / \mathrm{C}$ molar ratios.

The n-dodecane conversion and the selectivity of product gases such as $\mathrm{H}_{2}, \mathrm{CO}, \mathrm{CO}_{2}$, and $\mathrm{CH}_{4}$ were calculated according to Equations (1) and (2), respectively.

$$
\text { Dodecane conversion }(\%)=\left(\frac{F_{\mathrm{CO} \cdot \mathrm{Out}}+F_{\mathrm{CO}_{2} \cdot \mathrm{Out}}+F_{\mathrm{CH}_{4} \cdot \mathrm{Out}}}{F_{\mathrm{C}_{12} \mathrm{H}_{26} \cdot \mathrm{In}} \times 12}\right) \times 100
$$




$$
\text { Selectivity of product gas }(\%)=\left(\frac{F_{\text {product } \cdot \text { Out }}}{F_{\mathrm{H}_{2} \cdot \text { Out }}+F_{\mathrm{CO} \cdot \mathrm{Out}}+\mathrm{F}_{\mathrm{CO}_{2} \cdot \mathrm{Out}}+F_{\mathrm{CH}_{4} \cdot \mathrm{Out}}}\right) \times 100
$$

\section{Conclusions}

To enhance the efficiency of the nickel-alumina catalyst in the ATR of Solid Oxide Fuel Cell, polymer-modified incipient (PM) method was used to prepare the NA10-PM catalyst, which showed excellent performance and economic feasibility compared to other catalysts prepared by the impregnation method (IM), such as NA10-IM, RuA5-IM, RhA5-IM. The NA10-PM catalyst was initially auto-reduced by product gases obtained from thermal decomposition of dodecane. Notably, the crystal structure of the auto-reduced NA10-PM catalyst was completely changed to metallic nickel from $\mathrm{NiAl}_{2} \mathrm{O}_{4}$ of the fresh state. Moreover, the effects of various reaction parameters such as steam/carbon $(\mathrm{S} / \mathrm{C})$ and oxygen/carbon $\left(\mathrm{O}_{2} / \mathrm{C}\right)$ molar ratios were investigated to determine the optimum reaction conditions. The catalytic performance was more affected by the concentration of oxygen than by steam in the feed. The auto-reduced NA10-PM catalysts showed excellent conversion of dodecane and excellent catalytic stability compared to those of the $\mathrm{H}_{2}$-reduced NA10-IM and NA10-PM catalysts. Interestingly, the highest catalytic performance of auto-reduced NA10-PM was achieved for the reaction under the conditions of $\mathrm{S} / \mathrm{C}=1.23, \mathrm{O}_{2} / \mathrm{C}=0.25$, and GHSV $=12,000 \mathrm{~h}^{-1}$ at $750{ }^{\circ} \mathrm{C}$. Based on the BET and XRD results, it was proposed that the activated catalyst was more reduced by $\mathrm{CO}$ and $\mathrm{H}_{2}$ produced from the thermal decomposition of dodecane during the ATR reaction. Therefore, the auto-reduced NA10-PM catalyst was applied successfully for the auto-thermal reforming of dodecane.

Supplementary Materials: The following are available online at http:/ www.mdpi.com/2073-4344/8/9/371/s1, Figure S1: Thermal decomposition of $n$-dodecane with under $\mathrm{S} / \mathrm{C}=1.23$ and $\mathrm{O}_{2} / \mathrm{C}=0.25$ at $750{ }^{\circ} \mathrm{C}$. Figure $\mathrm{S} 2$ : (a) Nitrogen adsorption-desorption isotherms and (b) XRD patterns of fresh and auto-reduced NA10-PM at various temperature $\left(650,700\right.$, and $\left.750^{\circ} \mathrm{C}\right)$ for $2 \mathrm{~h}$.

Author Contributions: S.Y.J. and D.G.J. designed the experiments, S.C.L. and J.C.K. supervised the entire study; S.B.J. and D.G.J. performed the experiments and wrote the manuscript, D.S.H. and H.J.C. contributed to scientific discussions.

Acknowledgments: This work was supported by Priority Research Centers Program through the National Research Foundation of Korea (NRF) funded by the Ministry of Education, Science, and Technology (2009-0093819). This research was supported by Basic Science Research Program through the National Research Foundation of Korea (NRF) funded by the Ministry of Science, ICT \& Future Planning (No. 2017R1A2B4008275).

Conflicts of Interest: The authors declare no conflict of interest.

\section{References}

1. Aicher, T.; Lenz, B.; Gschnell, F.; Groos, U.; Federici, F.; Caprile, L.; Parodi, L. Fuel processors for fuel cell APU applications. J. Power Sources 2006, 154, 503-508. [CrossRef]

2. Lindström, B.; Karlsson, J.; Ekdunge, P.; De Verdier, L.; Häggendal, B.; Dawody, J.; Nilsson, M.; Pettersson, L.J. Diesel fuel reformer for automotive fuel cell applications. Int. J. Hydrogen Energy 2009, 34, 3367-3381. [CrossRef]

3. Zur Megede, D. Fuel processors for fuel cell vehicles. J. Power Sources 2002, 106, 35-41. [CrossRef]

4. Clarke, S.H.; Dicks, A.L.; Pointon, K.; Smith, T.A.; Swann, A. Catalytic aspects of the steam reforming of hydrocarbons in internal reforming fuel cells. Catal. Today 1997, 38, 411-423. [CrossRef]

5. Kaila, R.; Krause, A. Autothermal reforming of simulated gasoline and diesel fuels. Int. J. Hydrogen Energy 2006, 31, 1934-1941. [CrossRef]

6. Palm, C.; Cremer, P.; Peters, R.; Stolten, D. Small-scale testing of a precious metal catalyst in the autothermal reforming of various hydrocarbon feeds. J. Power Sources 2002, 106, 231-237. [CrossRef]

7. Wang, Z.; Huang, H.; Liu, H.; Zhou, X. Self-sustained electrochemical promotion catalysts for partial oxidation reforming of heavy hydrocarbons. Int. J. Hydrogen Energy 2012, 37, 17928-17935. [CrossRef]

8. Lakhapatri, S.L.; Abraham, M.A. Deactivation due to sulfur poisoning and carbon deposition on $\mathrm{Rh}-\mathrm{Ni} / \mathrm{Al}_{2} \mathrm{O}_{3}$ catalyst during steam reforming of sulfur-doped n-hexadecane. Appl. Catal. A Gen. 2009, 364, 113-121. [CrossRef] 
9. Xie, C.; Chen, Y.; Li, Y.; Wang, X.; Song, C. Influence of sulfur on the carbon deposition in steam reforming of liquid hydrocarbons over $\mathrm{CeO}_{2}-\mathrm{Al}_{2} \mathrm{O}_{3}$ supported $\mathrm{Ni}$ and Rh catalysts. Appl. Catal. A Gen. 2011, 394, 32-40. [CrossRef]

10. Li, L.; Jiang, B.; Tang, D.; Zheng, Z.; Zhao, C. Hydrogen production from chemical looping reforming of ethanol using $\mathrm{Ni} / \mathrm{CeO}_{2}$ nanorod oxygen carrier. Catalysts 2018, 8, 257. [CrossRef]

11. Palma, V.; Ruocco, C.; Meloni, E.; Ricca, A. Renewable hydrogen from ethanol reforming over $\mathrm{CeO}_{2}-\mathrm{SiO}_{2}$ based catalysts. Catalysts 2017, 7, 226. [CrossRef]

12. Mawdsley, J.R.; Krause, T.R. Rare earth-first-row transition metal perovskites as catalysts for the autothermal reforming of hydrocarbon fuels to generate hydrogen. Appl. Catal. A Gen. 2008, 334, 311-320. [CrossRef]

13. Bang, Y.; Han, S.J.; Seo, J.G.; Youn, M.H.; Song, J.H.; Song, I.K. Hydrogen production by steam reforming of liquefied natural gas (LNG) over ordered mesoporous nickel-alumina catalyst. Int. J. Hydrogen Energy 2012, 37, 17967-17977. [CrossRef]

14. Chen, X.; Gould, B.D.; Schwank, J.W. n-Dodecane reforming over monolith-based Ni catalysts: Sem study of axial carbon distribution profile. Appl. Catal. A Gen. 2009, 356, 137-147. [CrossRef]

15. Gould, B.D.; Chen, X.; Schwank, J.W. Dodecane reforming over nickel-based monolith catalysts. J. Catal. 2007, 250, 209-221. [CrossRef]

16. Gould, B.D.; Chen, X.; Schwank, J.W. n-Dodecane reforming over nickel-based monolith catalysts: Deactivation and carbon deposition. Appl. Catal. A Gen. 2008, 334, 277-290. [CrossRef]

17. Cheng, F.; Dupont, V. Steam reforming of bio-compounds with auto-reduced nickel catalyst. Catalysts 2017, 7, 114. [CrossRef]

18. Gould, B.D.; Tadd, A.R.; Schwank, J.W. Nickel-catalyzed autothermal reforming of jet fuel surrogates: N-Dodecane, tetralin, and their mixture. J. Power Sources 2007, 164, 344-350. [CrossRef]

19. Guo, Y.; Li, H.; Jia, L.; Kameyama, H. Trace Ru-doped anodic alumina-supported Ni catalysts for steam reforming of kerosene: Activity performance and electrical-heating possibility. Fuel Process. Technol. 2011, 92, 2341-2347. [CrossRef]

20. Modafferi, V.; Panzera, G.; Baglio, V.; Frusteri, F.; Antonucci, P. Propane reforming on Ni-Ru/GDC catalyst: $\mathrm{H}_{2}$ production for IT-SOFCs under SR and ATR conditions. Appl. Catal. A Gen. 2008, 334, 1-9. [CrossRef]

21. Zhong, X.; Xie, W.; Wang, N.; Duan, Y.; Shang, R.; Huang, L. Dolomite-derived Ni-based catalysts with Fe modification for hydrogen production via auto-thermal reforming of acetic acid. Catalysts 2016, 6, 85. [CrossRef]

22. Jung, S.Y.; Ju, D.G.; Lim, E.J.; Lee, S.C.; Hwang, B.W.; Kim, J.C. Study of sulfur-resistant Ni-Al-based catalysts for autothermal reforming of dodecane. Int. J. Hydrogen Energy 2015, 40, 13412-13422. [CrossRef]

23. Lee, W.S.; Ju, D.G.; Jung, S.Y.; Lee, S.C.; Ha, D.S.; Hwang, B.W.; Kim, J.C. n-Dodecane autothermal reforming properties of Ni-Al based catalysts prepared by various methods. Top. Catal. 2017, 60, 727-734. [CrossRef]

24. Amano, F.; Tanaka, T.; Funabiki, T. Auto-reduction of $\mathrm{Cu}(\mathrm{II})$ species supported on $\mathrm{Al}_{2} \mathrm{O}_{3}$ to $\mathrm{Cu}$ (i) by thermovacuum treatment. J. Mol. Catal. A Chem. 2004, 221, 89-95. [CrossRef]

25. Cheng, F.; Dupont, V. Nickel catalyst auto-reduction during steam reforming of bio-oil model compound acetic acid. Int. J. Hydrogen Energy 2013, 38, 15160-15172. [CrossRef]

26. Kim, D.; Lee, Y.; Kim, Y.; Mingle, K.; Lauterbach, J.; Blom, D.A.; Vogt, T.; Lee, Y. Ethylene epoxidation catalyzed by Ag nanoparticles on Ag-LSX zeolites formed by pressure-and temperature-induced auto-reduction. Chem. Eur. J. 2018, 24, 1041-1045. [CrossRef] [PubMed]

27. Matysik, J.; Hildebrandt, P.; Ludwig, B. Induction of photochemical auto-reduction of Cytochrome-c oxidase by an organic peroxide. Biochim. Biophys. Acta (BBA) Bioenergetics 2000, 1459, 125-130. [CrossRef]

28. Abad, A.; García-Labiano, F.; de Diego, L.F.; Gayán, P.; Adánez, J. Reduction kinetics of Cu-, Ni-, and Fe-based oxygen carriers using syngas $\left(\mathrm{CO}+\mathrm{H}_{2}\right)$ for chemical-looping combustion. Energy Fuels 2007, 21, 1843-1853. [CrossRef]

29. Bang, Y.; Seo, J.G.; Song, I.K. Hydrogen production by steam reforming of liquefied natural gas (LNG) over mesoporous $\mathrm{Ni}-\mathrm{La}-\mathrm{Al}_{2} \mathrm{O}_{3}$ aerogel catalysts: Effect of La content. Int. J. Hydrogen Energy 2011, 36, 8307-8315. [CrossRef]

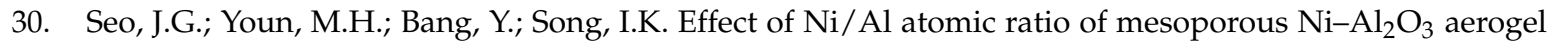
catalysts on their catalytic activity for hydrogen production by steam reforming of liquefied natural gas (LNG). Int. J. Hydrogen Energy 2010, 35, 12174-12181. [CrossRef] 
31. Boukha, Z.; Jiménez-González, C.; de Rivas, B.; González-Velasco, J.R.; Gutiérrez-Ortiz, J.I.; López-Fonseca, R. Synthesis, characterisation and performance evaluation of spinel-derived $\mathrm{Ni} / \mathrm{Al}_{2} \mathrm{O}_{3}$ catalysts for various methane reforming reactions. Appl. Catal. B Environ. 2014, 158, 190-201. [CrossRef]

32. Hao, Z.; Zhu, Q.; Jiang, Z.; Hou, B.; Li, H. Characterization of aerogel Ni/ $\mathrm{Al}_{2} \mathrm{O}_{3}$ catalysts and investigation on their stability for $\mathrm{CH}_{4}-\mathrm{CO}_{2}$ reforming in a fluidized bed. Fuel Process. Technol. 2009, 90, 113-121. [CrossRef]

33. Cheekatamarla, P.K.; Lane, A.M. Catalytic autothermal reforming of diesel fuel for hydrogen generation in fuel cells: I. Activity tests and sulfur poisoning. J. Power Sources 2005, 152, 256-263. [CrossRef]

(C) 2018 by the authors. Licensee MDPI, Basel, Switzerland. This article is an open access article distributed under the terms and conditions of the Creative Commons Attribution (CC BY) license (http:/ / creativecommons.org/licenses/by/4.0/). 